\title{
RESEARCH ON SCIENTIFIC SPORTS TRAINING OF STUDENTS MAJORING IN PHYSICAL EDUCATION
}

\author{
PESQUISA CIENTIIFICA SOBRE O TREINAMENTO ESPORTIVO DE ALUNOS DO CURSO DE \\ EDUCAÇÃO FÍSICA
}

Original Article

ARTIGO ORIGINAL

Artículo Original

\section{INVESTIGACIÓN SOBRE LA FORMACIÓN CIENTÍFICO-DEPORTIVA DE ESTUDIANTES DE LA CARRERA DE EDUCACIÓN FÍSICA}

Shaoping Zhao' 1 D

(Physical Education Professional)

1. Department of Teaching and Research of Physical Education, Wuhan Polytechnic University, Wuhan, China.

\section{Correspondence:}

Shaoping Zhao

Department of Teaching and Research of Physical Education, Wuhan Polytechnic University, Wuhan,430000, China.

512102623@qq.com

\begin{abstract}
Introduction: The organization of high-level sports teams in colleges and universities is an important measure for my country's competitive sports to break the traditional monopoly and monopoly pattern and go to the market and society in an all-around way. It helps to improve the cultural quality of Chinese athletes and cultivate new sports talents for comprehensive development. It can make full use of universities' multidisciplinary and high-tech advantages, increase the technological content of competitive training, and accelerate the improvement of sports level. Objective: This article intends to take the diving team as an example to explain the role and significance of scientific training in developing competitive sports in my country's ordinary colleges and universities and put forward suggestions for the establishment, organization, and implementation of scientific training. Methods: The scientific research support system used in the thesis includes: physiological and biochemical monitoring, health and sports injury monitoring, nutrition and weight monitoring, psychological consultation and monitoring, technical training support system, training quality management system, physical training support system, and athlete training database. Results: The in-depth research on diving training focuses on: (1) the detection and evaluation of diving technique training; (2) the training of divers'specific strength qualities; (3) the monitoring of nutrition and weight of female athletes; (4) Pre-match psychological training for outstanding diving athletes. Conclusions: The diving team's training shows that scientific and systematic training is an important guarantee for high-level student-athletes training in ordinary universities in my country. Level of evidence ll; Therapeutic studies - investigation of treatment results.
\end{abstract}

Keywords: Diving; Physical education and training; Professional training.

\section{RESUMO}

Introdução: A organização de equipes esportivas de alto nível em faculdades e universidades é uma medida importante para que os esportes competitivos em meu país quebrem o padrão tradicional de monopólio e entrem no mercado e na sociedade de maneira abrangente. Ajuda a melhorar a qualidade cultural dos atletas chineses e a cultivar novos talentos esportivos para um desenvolvimento integral. Pode tirar o máximo proveito das vantagens multidisciplinares e de alta tecnologia das universidades, aumentar o conteúdo tecnológico do treinamento competitivo e acelerar a melhoria do nivel esportivo. Objetivo: Este artigo visa tomar a equipe de mergulho como exemplo para explicar o papel e a importância da formação científica no desenvolvimento dos esportes competitivos em faculdades e universidades comuns do meu país e apresentar sugestões para o estabelecimento, organização e implementação da formação científica. Métodos: O sistema de apoio à investigação científica utilizado na tese inclui: monitorização fisiológica e bioquímica, monitorização de lesões na saúde e desportivas, monitorização da nutrição e peso, consulta e monitorização psicológica, sistema de apoio técnico à formação, sistema de gestão da qualidade da formação, apoio à formação física sistema e banco de dados de treinamento de atletas. Resultados: A pesquisa aprofundada sobre o treinamento em mergulho concentra-se em: (1) detecção e avaliação do treinamento em técnicas de mergulho; (2) treinar as qualidades especificas de força dos mergulhadores; (3) monitorar a nutrição e o peso dos atletas; (4) Treinamento psicológico pré-jogo para atletas de mergulho de destaque. Conclusões: O treinamento da equipe de mergulho mostra que o treinamento cientifico e sistemático é uma garantia importante para a formação de alunos-atletas de alto nível em universidades comuns de meu país. Nível de evidência ll; Estudos terapêuticos: investigação dos resultados do tratamento.

Descritores: Mergulho; Educação física e treinamento; Capacitação profissional.

\section{RESUMEN}

Introducción: La organización de equipos deportivos de alto nivel en colegios y universidades es una medida importante para que el deporte competitivo de mi país rompa el patrón tradicional de monopolio e ingrese al mercado y a la sociedad de manera integral. Ayuda a mejorar la calidad cultural de los atletas chinos y a cultivar nuevos talentos deportivos para un desarrollo integral. Puede aprovechar al máximo las ventajas multidisciplinarias y de alta tecnología de las universidades, aumentar el contenido tecnológico de la formación competitiva y acelerar la mejora 
del nivel deportivo. Objetivo: Este artículo pretende tomar al equipo de buceo como ejemplo para explicar el papel y la importancia de la formación científica en el desarrollo de deportes competitivos en los colegios y universidades ordinarios de mi país y presentar sugerencias para el establecimiento, organización e implementación de la formación científica. Métodos: El sistema de apoyo a la investigación científica utilizado en la tesis incluye: seguimiento fisiológico y bioquímico, seguimiento de la salud y lesiones deportivas, seguimiento de la nutrición y el peso, consulta y seguimiento psicológico, sistema de apoyo al entrenamiento técnico, sistema de gestión de la calidad del entrenamiento, sistema de apoyo al entrenamiento físico, y base de datos de entrenamiento de atletas. Resultados: La investigación en profundidad sobre el entrenamiento de buceo se enfoca en: (1) la detección y evaluación del entrenamiento de técnicas de buceo; (2) el entrenamiento de las cualidades de fuerza específicas de los buzos; (3) el seguimiento de la nutrición y el peso de las atletas; (4) Entrenamiento psicológico previo al partido para atletas de buceo destacados.

Conclusiones: La formación del equipo de buceo muestra que la formación científica y sistemática es una garantía importante para la formación de estudiantes-deportistas de al to nivel en las universidades ordinarias de mi país. Nivel de evidencia ll; Estudios terapéuticos: investigación de los resultados del tratamiento.

Descriptores: Buceo; Educación y entrenamiento físico; Capacitación profesional.

\section{INTRODUCTION}

At present, college sports teams have not yet entered the mainstream of China's competitive sports, and for many years they have rarely relied on their strength to cultivate athletes with international standards. The reason is that in addition to being affected by my country's current sports management system, college athletes have obvious shortcomings in terms of capital investment, coaching level, training conditions, competition opportunities, and logistical support, and they have not fully utilized the strong scientific and technological resources of universities. The introduction of advanced scientific theories and techniques into training is the main reason that hinders the rapid development of competitive sports in ordinary colleges and universities. ${ }^{1}$

\section{METHODS}

Assuming that the diving state is like a falling cylinder, the mass distribution is even. The height of the diver is the height of the cylinder, the human foot is the bottom of the cylinder, and the shoulder width of the human body is the cylinder's diameter. It is assumed that the pedaling process of the diving athlete is ignored; the wind speed and water speed are zero, which does not affect the athlete's falling; the turbulence effect of water is assumed to be ignored; the height, mass, and shoulder width of male and female divers are assumed to meet the international standards for diving athletes aged 20-25; When his feet are in contact with the bottom of the pool, the speed is just zero, reaching the safety threshold.

Because air resistance is not considered at this time, the athlete does free fall during the fall. The jumping platform's height is constant, so the athlete makes a uniformly accelerated motion with acceleration $g$ during the process of falling into the water, and the speed reaches the maximum when it reaches the surface. The whole process conforms to the law of conservation of energy. The following are the answers to the four processes: From the springboard to the horizontal plane:

$$
2 g l=v_{0}^{2}
$$

Already known, $I=28 \mathrm{~m}, g=9.8 \mathrm{~m} / \mathrm{s}^{2}$. So we can solve $V_{0}=23.426 \mathrm{~m} / \mathrm{s}$. From an energy perspective, the total energy conservation of the human-water system has the following formula:

$$
\frac{1}{2} m v_{0}^{2}=\frac{1}{2} m v_{1}^{2}+\frac{1}{2} \rho s v_{2}^{3} \times \Delta t+\rho s g v_{2}^{2} \times \Delta t^{2}
$$

$$
m\left(v_{0}-v_{1}\right)=\rho s v_{2}^{2} \times \Delta t
$$

When $t=0$, the collision relationship of $V_{1}, V_{2}$ is obtained by solving. The stages after the human body enter and fully enters satisfy the differential equations:

$$
m \frac{d^{2} h_{2}}{d t^{2}}=C A\left(\frac{d h_{2}}{d t}\right)^{2} / 2 g+\rho g s h_{1}-m g
$$

$$
-m \frac{d^{2} h}{d t^{2}}=f_{\text {water }}+F_{\text {float }}-m g \Rightarrow \frac{d v}{d h}=-\frac{c_{d} v}{2 h}-\frac{h g}{H v}+\frac{g}{v}
$$

When $R_{e}=4^{*} 10^{4}, C_{d}$ changes little and approaches 0.42 , where $L^{\prime}$ is the characteristic length corresponding to the cross-sectional area of the object, that is, the height of the person $\mathrm{H}$. Substituting $R_{\mathrm{e}} L^{\prime}$ ' into the equation: $v=0.0000712 \mathrm{~m} / \mathrm{s} 0 \mathrm{~m} / \mathrm{s}$. That is to say, the whole process of athletes from air to water can be regarded as the situation of $R_{\mathrm{e}}>1 \times 104$ Pa.s, and $C_{d}=0.42$ is obtained.

\section{RESULTS}

\section{The conception of scientific training of high-level sports teams in ordinary universities}

"Scientific training" uses scientific theories, techniques, and methods to guide sports training. Its realization is not a simple addition of science and sports training, but a systematic and complex process. The scientific transformation of traditional training to get rid of the long-term subjective experience-based model involves the training process itself and several factors that impact training. Simultaneously, we should also realize that "scientific training" does not mean the "quantification" of the entire training process. The current scientific training cannot completely replace or exclude some long-term accumulated experience in training.

\section{The basic elements and structure of scientific training}

"Scientific training" has its structure and system. From a methodological point of view, different sports and objects have commonalities in scientific training's basic composition. Generally speaking, scientific training consists of four aspects: personnel, subjects, 
funding, and equipment. Figure 1 is a schematic diagram of the basic structure of scientific training.

The training group composed of coaches and scientific researchers is one of the main components of scientific training. It is responsible for the design and implementation of the entire scientific training plan. The selection and selection of scientific research personnel is an important factor in determining scientific training quality. According to the requirements of special events and athletes, the scientific research team members should be selected from three aspects: professional category, professional level, and investment time..$^{2-3}$

The "topic" of scientific training is not equivalent to sports scientific research topics, nor is it entirely the application of research results in training. It is scientific auxiliary support for training (application of research results) and a deep level of certain key links or problems. The sum of research (research topics). In the training process, we should correctly understand the relationship between the two and distinguish their similarities and differences. Figure 2 is a schematic diagram of scientific training content, which shows the difference and interrelationship between general scientific auxiliary support and in-depth research in scientific training.

The article uses scientific theories, methods, and means to support the sports training process as an important part of scientific training. It integrates science and technology into daily training work, a considerable part of which does not appear in the form of "research topics," nor is it necessarily the frontier of scientific research. It is closely related to the reality of training, closely surrounding coaches and athletes' needs, improving training efficiency and sports performance, and providing comprehensive, meticulous, and long-term services to the training process.

In-depth research on key links and issues of training is another important part of scientific training. To fully mobilize and give play to researchers' enthusiasm and role in scientific training, it is necessary to integrate their theories and knowledge, including the latest high-tech

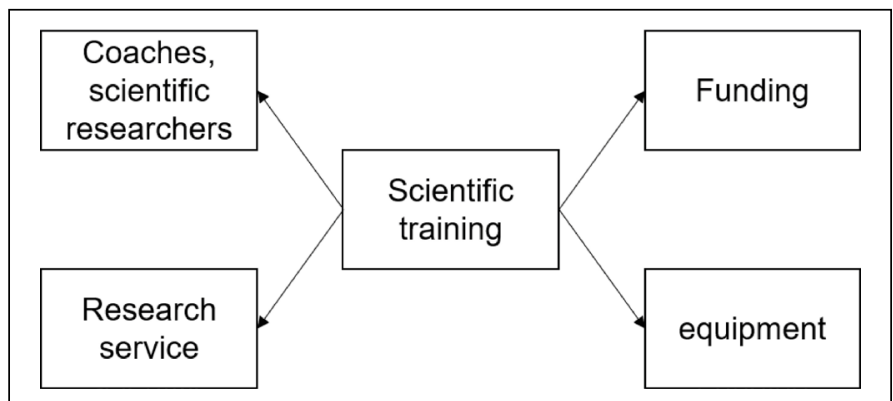

Figure 1. The basic structure of scientific training. technology, with sports training and form in the process of scientific training. Multiple interdisciplinary research topics. These "topics" should reflect the characteristics of multidisciplinary high-tech in colleges and universities and integrate with the practice of sports training.

\section{Typical case analysis: scientific training of diving team}

The diving team is a young diving team formed in recent years. Its establishment's original intention is to introduce diving, a project that integrates strength, bravery, and beauty into universities, and to take advantage of the multidisciplinary and high-tech advantages of comprehensive universities to train high-level diving athletes through scientific training. Facing such a sports team with the main feature of "the combination of learning and training,"we realized that traditional training methods could no longer meet athletes' needs, and we must seek new paths and breakthrough points in training. Thus, we have carried out long-term planning and design for the training of the diving team, taking the scientific level's improvement as the focus of the team's work, and positioning it as scientific research support for training in-depth research on certain key links or problems. Study two aspects. We believe that these two aspects should be given equal attention in scientific training and should not be neglected.

\section{Design of scientific training}

Based on the analysis and understanding of the scientific research results of diving at home and abroad and the existing diving training problems, we have planned and designed the scientific training of diving teams. The diving team has fully considered and prepared for future scientific training at the beginning of its establishment. We have hired coaches with rich training practical experience and higher educational level as the head coach of the diving team and introduced a group of high Sports researchers with academic qualifications and rich scientific research experience. ${ }^{4}$ Figure 3 is a schematic diagram of the scientific research support system of the diving team.

\section{DISCUSSION}

We have noticed that the main development trend of current sports scientific research is manifested in the application of multidisciplinary and high-tech in sports and manifested in the substantial tilt of scientific research towards training practice. People are no longer satisfied with sports scientific research that is separated from training practice and staying at the stage of "discovering" problems but pays more attention to scientific research projects closely integrated with training and can "solve" problems. Therefore, we try to choose technical or training problems that impact diving performance as the entry point for research. ${ }^{5}$ The research

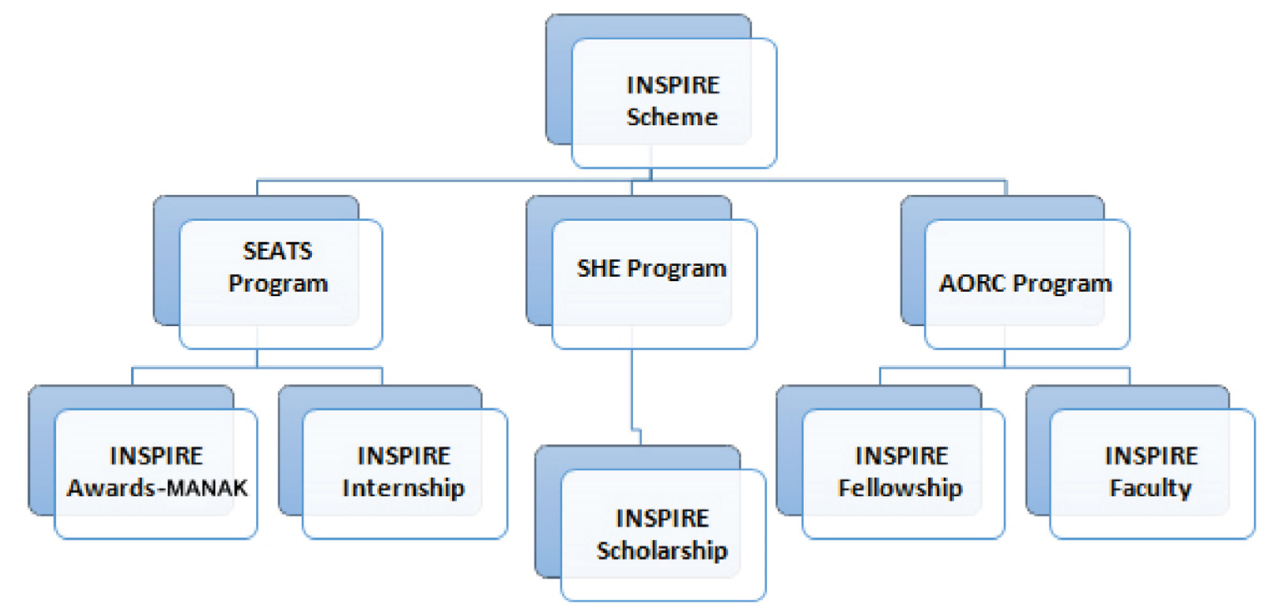

Figure 2. Schematic diagram of scientific training content. 


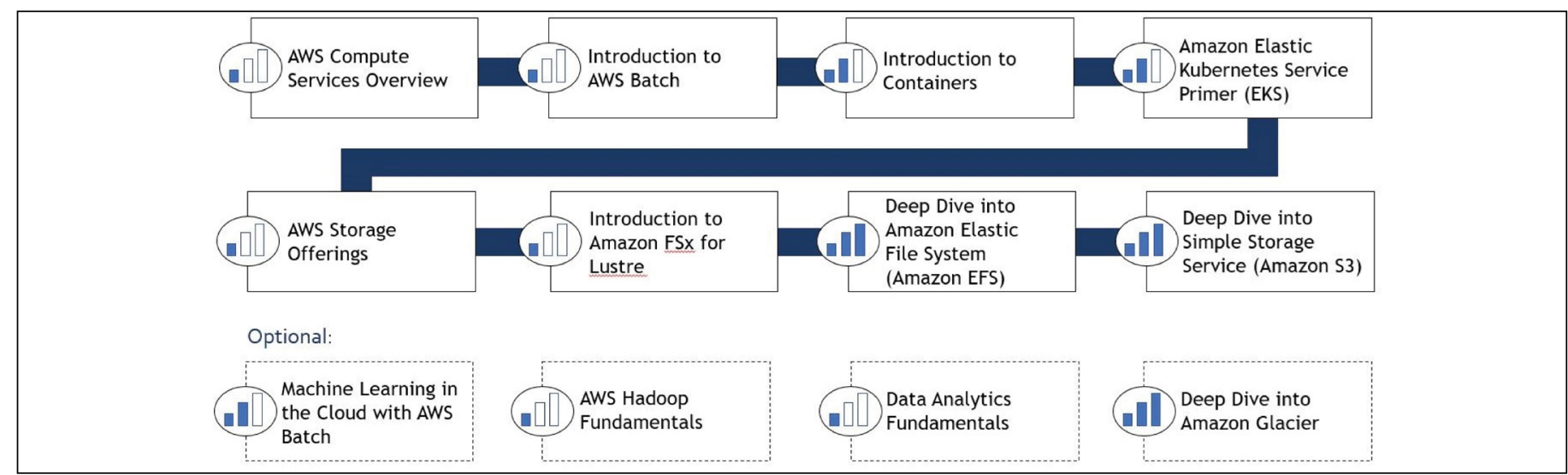

Figure 3. Research support system for the diving team.

results can help athletes solve practical problems in technology and training and reveal and summarize the laws and experience of diving training and promote Improve the level of diving research. According to the scientific research status of diving and our existing research conditions, we will focus on the following four aspects of in-depth research.

\section{Testing and evaluation of diving technique training}

The detection and analysis of sports technology is an important part of achieving the sports training process's overall control. The process can be summarized as: using modern testing instruments and equipment to collect sports technical information during the training and competition of athletes, using relevant scientific theories and methods to process and analyze the obtained data, and establish standards for evaluating technical training effects, and then according to Analyze the results to control the training process, and evaluate, predict and simulate the development of technical training and technical movements. ${ }^{6}$

\section{Special strength training for divers}

Fast power is one of the main qualities of a diving athlete. Obtaining the highest possible take-off height and fast tossing speed is an important prerequisite and guarantee for improving the quality and difficulty of diving. We use biomechanics, electromyography, and training methods to detect and evaluate the specific strength level of divers of different ages and levels and their relationship with key biomechanical indicators of diving techniques and obtain and determine diving. The quantitative correspondence between the quality of technical movements and the level of specific strength establishes the development model of diving athletes' specific strength.

\section{Nutrition and weight monitoring of female athletes}

We will take the promising female divers aged 8 to 13 as the key service and research objects and assist coaches and athletes in solving "rapid weight gain and uncontrollable weight gain" during adolescence through nutrition and training. The research on this subject will be carried out in cooperation with the University of Sports. We will make full use of the respective research advantages of the University of Sports and the good scientific training atmosphere of the diving team.

\section{Recommendations for system training}

The diving team's training shows that scientific training is an important guarantee for high-level student-athletes training in ordinary universities in our country. Through a summary of scientific training in recent years, we believe that the following issues have an important impact on the signification of competitive sports training in ordinary colleges and universities, and should arouse our attention:

We should fully realize that in terms of high-level athletes' training, the advantages of ordinary colleges and universities are mainly reflected in multidisciplinary and high-tech aspects. We should apply advanced scientific theories and technologies as much as possible to the training of competitive sports and increase training. The high-tech content is the only effective way for regular universities to train national and even world-level college athletes as soon as possible. Therefore, while preparing to establish a sports team, we should seriously consider scientific training and plan and design in terms of personnel, equipment, and funds.

\section{CONCLUSION}

From a methodological point of view, different sports and objects have commonalities in scientific training's basic composition. Generally speaking, scientific training consists of four aspects: personnel, subjects, funding, and equipment. The use of scientific theories, methods, and means to support the sports training process is an important part of scientific training. This additional support integrates science and technology into daily training work, and a considerable part of the work does not appear in the form of "research topics," nor is it necessarily the frontier of scientific research. But it is closely related to the reality of training, closely surrounding the needs of coaches and athletes, improving training efficiency, increasing sports performance, and providing comprehensive, meticulous, and long-term services to the training process.

The author declare no potential conflict of interest related to this article

AUTHORS' CONTRIBUTIONS: The author made significant contributions to this manuscript. Shaoping Zhao: writing and performing surgeries; data analysis and performing surgeries; article review and intellectual concept of the article.

\section{REFERENCES}

1. HuXR. Ideological conflicts behind mutual belief: the termination of the'dual-registration policy'and the collapse of an effective elite diving system in China. Sport in Society. 2019;22(8): 1362-81.

2. Shehata KA. Effect of using Trampoline on the development of functional efficiency of the vestibular apparatus on composite balance for One and Half Forward Somersault pike in diving sport. International Journal of Sports Science and Arts. 2019;11(11):97-122.

3. Schipke JD, Lemaitre F, Cleveland S, Tetzlaff K. Effects of breath-hold deep diving on the pulmonary system. Respiration. 2019;97(5):476-83.
4. Otto MG, Martinez JM, Barnhill C. The transitioning process: A qualitative case study of international swimming and diving student-athletes competing in the NCAA. JAS. 2020;6(1):52-80.

5. Elbaradie MY. Evaluating marine safety factors and their relationship to diving accidents and diseases. JASS. 2020;10(1):9-20.

6. Solich-Talanda M, Mikołajczyk R, Roczniok R, Żebrowska A. The effect of breath-hold diving on selected adaptive mechanisms in the circulatory-respiratory system in simulated static and dynamic apnoea. Baltic Journal of Health and Physical Activity. 2019;11(1):7-17. 